\title{
Stress Indicators and Behavioural End-Points of Lybriodrillus violaceous Exposed to Petroleum Products Contaminated Soil
}

\author{
Ogunlaja Aemere $^{1 *}$ and Ogunlaja Olumuyiwa Olufisayo ${ }^{2}$
}

${ }^{1}$ Redeemer's University, College of Natural Sciences, Biological Sciences Department, Redemption camp, Mowe, Ogun State, Nigeria ${ }^{2}$ Lead City University, Biochemistry Department, Ibadan-Lagos Express-way, Ibadan, Oyo State, Nigeria

\begin{abstract}
The effect of fresh gasoline contaminated soil (GS), fresh diesel contaminated soil (DS) and a 3 years old oil spill soil on indigenous tropical earthworm, Lybiodrillus violaceous, was carried out using five acute toxicity tests. This included coiling exhibition, swollen clitellium, 14 days survival test, $48 \mathrm{hrs}$ avoidance response test and 56 days juvenile production test. Soil samples from a non-contaminated soil (NCS) were used as control. The exposure of earthworms to GS and DS soils resulted in exhibition of coiling response and swollen clittelium region. For survival test, results showed $60 \%$ and $20 \%$ survival for GS and DS respectively while $80 \%$ and $100 \%$ survival were recorded for CS and NCS. Avoidance test showed that there was 8:2 (NCS:DS), 6:4 (NCS:GS) and 5:5 (NCS:CS) ratio of L.violaceous present in soil types. Study on Juvenile production showed that there were no juveniles produced in both GS and DS contaminated soil, however, there were juvenile production recorded in CS and NCS. The negative impact of all toxicity tests on L.violaceous was more in diesel contaminated soil compared to gasoline contaminated soil and least in the 3 year old spill soil. The results indicated negative effect of diesel and gasoline contamination on L.violaceous.
\end{abstract}

Keywords: Acute toxicity; Lybriodrillus violaceous; Diesel; Gasoline; Soil

\section{Introduction}

In recent times, a growing number of residential and office area have become polluted with gasoline and diesel owing to the fact that most of Nigeria populace has resorted to the use of diesel and gasoline generators as an alternative source of electricity. The issue of pipeline vandalization had also become common placed which is also a source of petroleum pollution. Pollutants from oil spills have far reaching effect on their environment acutely and long after the incidents have occurred. These pollutants are known to percolate deep into the soils [1] where some remain recalcitrant, posing prolong threats to organisms [2,3].

Earthworms form one of the major macro-fauna among soil biota; they play an essential role in maintaining the structure and fertility of soils, recycling nutrients, improve their habitat and are important decomposers in a food web, sustaining dynamic equilibrium in the soil [4-6]. Earthworms are relevant test-organisms in ecotoxicological tests representing $60-80 \%$ of the total soil animal/invertebrate biomass. Because of their ubiquitous nature and sensitivity, earthworms play a vital role in estimating the effect of pollutants on terrestrial environment [1].

Mortality or reproduction rate tests are important ecological parameters used to determine the consequence of exposure to chemicals in soils. The emigration of earthworms and the subsequent loss of their beneficial functions in soil lead to a degradation of soil qualities. Furthermore, reduction in earthworms' population from an area might also affect the abundance and distribution of their vertebrate predators. This event consequently has an indirect impact on an ecosystem [7]. The regular endpoints evaluations in earthworm ecotoxicology guideline; mortality and reproduction rates alone cannot indicate the influence of pollutants on population since changes in behavior such as substrate avoidance can result in emigration which impinges on soil ecosystems. It is therefore not realistic and would be a wrong prediction to depend on mortality and reproduction results alone for long term effects on organisms exposed to oil spills [1].
Although, the use of earthworm for toxicity testing has been over the last 20 years and is currently used as a basis for international regulatory guidelines in EU for risk assessment [8] there have been with several problems [9]. The most widely used test species is $E$. fetida. Puzzling questions have arisen with the use of $E$. fetida because it has been argued that it is more tolerant than most earthworms to contaminants $[10,11]$ and it is not found in all natural soils [12]. Sometimes field-collected "wild" earthworms could be used for toxicity testing however their genetic background and local subspecies are not well known. Hence, there can be problems extrapolating results from laboratory to field scale. However such research could also be done as they give an insight into the actual situation on site which might be necessary to propose policies within such regions.

Several works on the toxicity of contaminants on Eisenia fetida, [7,13,14] Lumbricus sp [15], Eudrilus engeniae [1] have been reported. However, reports on toxicity of local tropical earthworm species are rare. The objective of this study is to use simple and easy stress indicators including coiling reaction, survival test, avoidance response test and juvenile production to observe in local tropical earthworms exposed to gasoline and diesel contaminated soil and soil from Agaye community. This community had been exposed to repeated oil spill (undefined) due to vandalization of petroleum pipelines, a common occurrence in Nigeria. Soil from a non-contaminated area was used as control. These toxicity parameters give insight into the severity of the different petroleum products to the most abundant and dominant

*Corresponding author: Ogunlaja Aemere, Redeemer's University, College of Natural Sciences, Biological Sciences Department, Redemption camp, Mowe, Ogun State, Nigeria, E-mail: aigbomere@yahoo.com

Received August 28, 2012; Accepted November 09, 2012; Published November 12, 2012

Citation: Aemere O, Olufisayo OO (2012) Stress Indicators and Behavioural EndPoints of Lybriodrillus violaceous Exposed to Petroleum Products Contaminated Soil. J Environ Anal Toxicol 2:159. doi:10.4172/2161-0525.1000159

Copyright: (C) 2012 Aemere O, et al. This is an open-access article distributed under the terms of the Creative Commons Attribution License, which permits unrestricted use, distribution, and reproduction in any medium, provided the original author and source are credited. 
earthworm species (Lybriodrillus violaceous, [16]) identified in Agaye soil.

\section{Experimental}

\section{Test animal}

Lybiodrilus violaceous, were collected by hand picking from Agaye soil, which was humus with high organic content. The earthworms were collected from the same site in order to reduce variability in biotype. Earthworms were brought into laboratory in plastic buckets containing soil collected from the same soil and supplemented with half-boiled, ground water-leaf (Talinium triangulare) [17] and then moistened with distilled water. They were left to acclimatize for 12 days. Subsequently, earthworms were fed with leaflets of lettuce Nymphea lotus, 3 g per 10 worms every 4 days throughout the period of all studies carried out [1]. Adult earthworms of length $18 \mathrm{~cm}-20 \mathrm{~cm}$ and body weight $1.3 \mathrm{~g}-1.5 \mathrm{~g}$ were picked and used for the bioassay tests

\section{Control soil}

Control soil was collected from a garden soil in Ibadan which had been void of any crop protection product within the last one year of use and also void of organic fertilizer within the last six months of use for testing [18]. All recommended manipulations for natural soils by ASTM, 2004 was also applied. Analysis of micro pollutants prior to use was also done. The soil had $37 \%$ sand, $13 \%$ clay and $50 \%$ silt. The $\mathrm{pH}$ values of control soils range from 7.1 to 7.7.

\section{Soil preparation and contamination}

This was done according the method adopted [1] with slight modifications. Soil samples were collected from generator areas using strictly gasoline and diesel respectively from redemption camp, Ogun state, Nigeria. All soil samples were air-dried, macerated and sifted through a $0.30 \mathrm{~mm}$ (mesh size) screen so as to standardize the grain size. Diesel and gasoline contaminated soil were properly mixed with control soil at proportion 1:1 (50\%) and 1:10 (10\%) respectively. Each soil mixture was moistened with $5 \mathrm{ml}$ of distilled water. $1 \mathrm{~kg}$ of $100 \%$, $50 \%$ and $10 \%$ prepared soil (diesel and gasoline soil) were then placed in plastic vessel of size $20 \mathrm{~cm}$ in diameter (base) by $35 \mathrm{~cm}$ height and $35 \mathrm{~cm}$ in diameter (top), the bottom was perforated while the top was covered with mesh and made to stay with elastic bands. $1 \mathrm{~kg}$ of fresh soil from Agaye community and control garden soil from a non oil contaminated soil were also prepared as described above.

\section{Experimental set-up}

$1 \mathrm{~kg}$ of each type of soil; GS (gasoline contaminated soil), DS (diesel contaminated soil), CS (soil from Agaye community) and NCS (non-contaminated garden soil), were placed in vessels and labelled accordingly. 10 adult earthworms were applied to each vessel and this was done in triplicate. Set-up was arranged in a randomized block design and was used for the following toxicity studies; coiling response, swollen clittelium, 14 days survival test, $48 \mathrm{hrs}$ avoidance response test and 56 days juvenile.

\section{Avoidance test}

A two chambered test system was used [7]; $1 \mathrm{Kg}$ of each soil, gasoline (GS), diesel (DS) and contaminated soil (CS) were added to one of the chambers. $1 \mathrm{~kg}$ of non-contaminated soil (NCS) was then applied to the second chamber of each system; the two chambers were entirely separated so as to prevent mixing up of both soil types. The separator was then removed thereby creating a groove in between both soil types; this was done to allow free movement of earthworms between the two chambers. 10 earthworms each were added to the groove of each setup. Each chamber was covered with mesh and made to stay with the aid of elastic band and left for $48 \mathrm{hrs}$. Prior to counting, the separator was put back in place (in groove), each soil type removed separately and the number of earthworms in each chamber was counted after $48 \mathrm{hrs}$ for each set-up and recorded.

\section{Coiling and swollen clitellum, survival/juvenile production tests}

10 earthworms were applied to each set-up described above (i.e. DS, GS, NS and NCS with varying concentrations). The vessels were thereafter covered with meshes which were kept in place by elastic band. The number of surviving earthworms, coiled animals and swollen clitellum in various treated soils were observed and recorded 1 day, 2 days, 5 days and 7 day period. Vessels with survivals were left till the $56^{\text {th }}$ day and the number of juveniles were counted and recorded.

\section{Statistics}

Means of earthworms numbers in the various toxicity test were done and t-test analysis was using SPSS version16, package.

\section{Results}

\section{Survival and coiling reaction}

Adult earthworm, L.violaceous, exposed to gasoline and diesel soil mixtures were observed for survival and coiling. Result showed that about $14.29-66.67 \%$ and $20-100 \%$ of the exposed animal exhibited coiling for gasoline and diesel respectively. The highest percentage of coiled earthworms was recorded within the first 24 hours of observation (Tables 1 and 2).

\begin{tabular}{|l|l|l|l|l|l|}
\hline Soil type & Day 1 & Day 2 & Day 5 & Day 7 & Day 14 \\
\hline GS $(100 \%)^{*}$ & $6(83.33)$ & $5(60)$ & $5(40)$ & $4(33.33)$ & $4(0)$ \\
\hline GS $(50 \%)^{*}$ & $8(87.5)$ & $7(57.14)$ & $7(42.86)$ & $7(33.33)$ & $7(0)$ \\
\hline GS $(10 \%)^{*}$ & $9(33.33)$ & $8(25)$ & $7(14.29)$ & $7(14.29)$ & $7(0)$ \\
\hline NCS & $10(10)$ & $8(12.5)$ & $8(0)$ & $8(0)$ & $8(0)$ \\
\hline CS & $9(0)$ & $9(0)$ & $9(0)$ & $9(0)$ & $8(0)$ \\
\hline
\end{tabular}

*=significantly different at $\mathrm{P}<0.05$

The t-test results comparing means of surviving earthworms exposed to gasoline contaminated soil showed that there was significant $(P<0.05)$ difference in all treated media compared to the control media (NCS) but not with the contaminated soil (CS) from Agaye.

Table 1: Mean number of surviving earthworms/(Percentage of coiled ones in Parenthesis) of exposed to gasoline contaminated soil.

\begin{tabular}{|l|l|l|l|l|l|}
\hline Soil type & Day 1 & Day 2 & Day 5 & Day 7 & Day 14 \\
\hline DS $(100 \%)^{\star}$ & $0(0)$ & $0(0)$ & $0(0)$ & $0(0)$ & $0(0)$ \\
\hline DS $(50 \%)^{*}$ & $3(100)$ & $3(66.66)$ & $2(50)$ & $2(0)$ & $1(0)$ \\
\hline DS $(10 \%)^{*}$ & $6(83.33)$ & $6(50)$ & $6(33.33)$ & $5(20)$ & $5(0)$ \\
\hline NCS & $10(10)$ & $8(12.5)$ & $8(0)$ & $8(0)$ & $8(0)$ \\
\hline CS & $9(0)$ & $9(0)$ & $9(0)$ & $9(0)$ & $8(0)$ \\
\hline
\end{tabular}

*=significantly different at $\mathrm{P}<0.05$

The t-test results comparing means of surviving earthworms exposed to diese contaminated soil showed that there was significant $(P<0.05)$ difference in all treated media compared to the control media (NCS) but not with the contaminated soil, NCS ( $P>0.05)$ from Agaye

Table 2: Mean number of surviving earthworms and (Percentage of coiled ones in Parenthesis) of exposed to diesel contaminated soil. 


\section{Swollen clitellum}

Adult earthworm, L.violaceous, exposed to gasoline and diesel soil mixtures were observed for clittelium swellings on Day 1, 2, 5 and 7. Results (Tables 3 and 4), shows that mean number of earthworms with swollen clittelium increased with increasing days of exposure. No swelling was observed in animals exposed to lower concentration soil mixture $(10 \% / 50 \%$ and $10 \%$ for gasoline and diesel respectively). There were also no clitella swellings in CS and NCS. Statistical comparisons also showed that there was significant $(\mathrm{P}<0.05)$ difference in the mean number of earthworms with swollen clitellum in treated media compared to the control media except with CS.

\section{Juvenile production}

The mean number of juveniles observed after 52 days showed that there was no juvenile produced for all set-up exposed to the various soil mixture of gasoline and diesel whereas 10 and 18 juveniles were recorded in CS and NCS respectively.

\section{Discussion}

A lot of studies on environmental impact of contaminants have been done with both aquatic and terrestrial biota of economic importance without much consideration of other less economic important biota like earthworms. The exposure of soil mixtures of $100 \%, 50 \%$ and $10 \%$ of gasoline and diesel respectively resulted in exhibition of coiling response and swollen clitella region in exposed animals.

The aforementioned responses are very useful indicators of petroleum related contamination or other forms of stress in the terrestrial ecosystem, they can be very easily detected in the field and their uses in contaminated sites have been reported [1,19-21]. They can be used for the detection of stress in the soil. Such responses could also be important tools for monitoring effectiveness of remediation/cleanup programme as well as mitigation exercises $[1,22,23]$.

Report indicates that earthworms are generally not sensitive to acute effects of some pesticides like DDT [24]. However, [25] Cook et

\begin{tabular}{|l|l|l|l|l|l|}
\hline Soil type & Day 1 & Day 2 & Day 5 & Day 7 & Day 14 \\
\hline GS $(100 \%)^{\star}$ & $2(33.33)$ & $3(60)$ & $3(60)$ & $4(100)$ & $4(100)$ \\
\hline GS $(50 \%)^{\star}$ & $0(0)$ & $2(28.57)$ & $3(42.86)$ & $3(42.86)$ & $4(57.14)$ \\
\hline GS $(10 \%)$ & $0(0)$ & $0(0)$ & $1(14.29)$ & $2(28.57)$ & $3(42.86)$ \\
\hline NCS & $0(0)$ & $0(0)$ & $0(0)$ & $0(0)$ & $0(0)$ \\
\hline CS & $0(0)$ & $0(0)$ & $0(0)$ & $0(0)$ & $0(0)$ \\
\hline
\end{tabular}

*=significantly different at $\mathrm{P}<0.05$

The t-test results comparing means of swollen clitellum in surviving earthworms exposed to gasoline contaminated soil showed that there was significant $(\mathrm{P}<0.05)$ difference in GS with $100 \%$ and $50 \%$ mixture compared to the control media (NCS) where as there was no significant difference in GS with $10 \%$ mixture and CS $(P>0.05)$ compared to the control media.

Table 3: Mean number of swollen clitella earthworms (Percentage in Parenthesis) exposed to gasoline contaminated soil.

\begin{tabular}{|l|l|l|l|l|l|}
\hline Soil type/Conc (ml/kg) & Day 1 & Day 2 & Day 5 & Day 7 & Day 14 \\
\hline DS $(100 \%)^{*}$ & $4(75)$ & $4(100)$ & $3(100)$ & $0(0)$ & $0(0)$ \\
\hline DS $(50 \%)^{*}$ & $6(33.33)$ & $5(66.66)$ & $4(75)$ & $3(100)$ & $1(100)$ \\
\hline DS $(10 \%)^{*}$ & $0(0)$ & $1(16.67)$ & $2(66.66)$ & $3(60)$ & $4(80)$ \\
\hline NCS & $0(0)$ & $0(0)$ & $0(0)$ & $0(0)$ & $0(0)$ \\
\hline CS & $0(0)$ & $0(0)$ & $0(0)$ & $0(0)$ & $0(0)$ \\
\hline
\end{tabular}

*=significantly different at $\mathrm{P}<0.05$

Table 4: Mean number of swollen clitella in surviving earthworms (Percentage in Parenthesis) exposed to diesel contaminated soil. al. reported that DDT did not have effect on the number of earthworm spp but on cocoon production, hatchability and juvenile production.

The coiling response of earthworm inhabiting contaminated environment is an important parameter for observation as it serves as an early indicator of stress in the environment. Reports of coiling response of the earthworm Eudrilus Eugenia showed a negative impact of Forcados crude oil [1] which supports the findings from this study.

For survival test, results showed $60 \%$ and $20 \%$ survival for GS and DS respectively while $80 \%$ and $100 \%$ survival was recorded for CS and NCS. The higher percentage of survival in CS compared to NCS (control) could be because the organisms are known to be adapted to their original environment [26]. Avoidance test showed that there was 8:2 (NCS:DS), 6:4 (NCS:GS) 5:5 (NCS:CS) survival ratio of Lybriodrillus violaceous. Study on Juvenile production showed that there were no juveniles produced in both GS and DS contaminated soil, however, there were juvenile production recorded in CS and NCS. A report [27] had also shown that soils polluted with petroleum effluent caused $40 \%$ death, swelling, body lesions, stiffening, coiling, low reproduction and reduction in populations of Eudrilus Eugenia.

\section{Conclusion}

The negative impact of all toxicity tests on L.violaceous was more severe with diesel contaminated soil followed by gasoline contaminated soil compared to the 3 year old oil spilled soil, this could be due to the higher density and low volatility of diesel compared to gasoline. L.violaceous showed less swollen clitella effect than survival and coiling in all soil mixtures of gasoline and diesel contaminated soil. Also, the soil sample from 3 years old oil spill showed a mild impact on the earthworm species as it would have been void of most of the volatile contaminants, however, the slight negative impact on survival could be because of recalcitrant hydrocarbons present in the soil sample.

\section{Acknowledgement}

We hereby appreciate the students in Agaye community school, lje-Ododo who voluntarily helped out with the collection of earthworms.

\section{References}

1. Otitoloju A (2005) Stress indicators in earthworms Eudrilus eugeniae inhabiting a crude oil contaminated ecosystem. Journal of life and physical sciences, acta SATECH 2: 1-5.

2. Hozumi T, Tsutsumi $H$, Kono M (2000) Bioremediation on the shore after an oil spill from the Nakhodka in the sea of Japan. I. Chemistry and Characteristics of Heavy Oil Loaded on the Nakhodka and Biodegradation Tests by a Bioremediation Agent with Microbiological Cultures in the Laboratory. Marine Pollution Bulletin 40: 308-314

3. Peterson CH (2001) The "Exxon Valdez" oil spill in Alaska: Acute, indirect and chronic effects on the ecosystem. Advances in Marine Biology 39: 1-103.

4. Radha DK, Natchimuthu K (2010) The Role of Earthworms in Tropics with Emphasis on Indian Ecosystems. Applied and Environmental Soil Science.

5. Römbke J, Jänsch S, Didden W (2005) The use of earthworms in ecologica soil classification and assessment concepts. Ecotoxicology and Environmental Safety 62: 249-265.

6. Emmerling C, Paulsch D (2001) Improvement of earthworm (Lumbricidae) community and activity in mine soils from open-cast coal mining by the application of different organic waste materials. Pedobiologia 45: 396-407.

7. Schaefer M (2003) Behavioural Endpoints in Earthworm Ecotoxicology. Journal of Soils \& Sediments 3: 79-84.

8. Langdon CJ, Winters C, Sturzenbaum SR, Morgan Aj, Charnock JM, et al (2005) Ligand arsenic complexation and immunoperoxidase detection of metallothionein in the earthworm Lumbricus rubellus inhabiting arsenic-rich soil. Environ Sci Technol 39: 2042-2048. 
Citation: Aemere O, Olufisayo OO (2012) Stress Indicators and Behavioural End-Points of Lybriodrillus violaceous Exposed to Petroleum Products Contaminated Soil. J Environ Anal Toxicol 2:159. doi:10.4172/2161-0525.1000159

Page 4 of 4

9. Lowe C, Butt $K$ (2006) The use of earthworms as a tests organisms in ecotoxicology, Critical review, The 8 International Symposium on Earthworm Ecology 4-9 September 2006,.Kraków, Poland.

10. Best EP, Tatem HE, Geter KN, Wells ML, Lane BK (2008) Effects, uptake, and fate of 2,4,6-trinitrotoluene aged in soil in plants and worms. Environ Toxicol Chem 27: 2539-2547.

11. Voua Otomo P, Reinecke SA (2010) Increased cytotoxic and genotoxic tolerance of Eisenia fetida (Oligochaeta) to cadmium after long-term exposure. Ecotoxicology 19: 362-368.

12. Spurgeon DJ, Hopkin SP (1996) Effects of Metal-Contaminated Soils on the Growth, Sexual Development, and Early Cocoon Production of the Earthworm Eisenia fetida, with Particular Reference to Zinc. Ecotoxicol Environ saf 35: 86-95.

13. Van Rensburg L, Maboeta M, Van Rensburg PJ (2008) Earthworm (Eisenia Fetida) bioassay to assess the possible effects of platinum tailings disposal facilities on the environment along a gradient. Applied ecology and environmental research 6: 13-19.

14. Lors C, Perie F, Grand C, Damido D (2009) Benefits of ecotoxicological bioassays in the evaluation of a field biotreatment of PAHs polluted soil. Global NEST Journal 11: 251-259.

15. Martina GV, Jos PMV, TjallingJ, Wolterbeek HT, Syraalen NMV, et al. (2005) Biphasic elimination and uptake kinetics of $\mathrm{Zn}$ and $\mathrm{Cd}$ in the earthworm Lumbricus rubellus exposed to contaminated floodplain soil. Soil Biology and Biochemistry 37: 1843-1851.

16. Beddard, Owa SO, Moreyibi HO, Dedeke GA, Olojo FO and Fasunwa OO (2004). Earthworm created micro environment around roots of lowland rice, Journal of science and Technology 11: 5261-5270.

17. Fafioye O, Owa S (2000) Effect of oil contamination on mortality of a eudriline earthworm, Eudrilus eugeniae. Nigerian Journal of Science 34: 355-361.
18. OECD (Organisation for Economic Co-operation and Development) (1984) Guideline for testing of chemicals, Earthworm, Acute Toxicity Tests.

19. Otitoloju A, Adeoye O (2002) Tainting and weight changes of Tilapia guineensis exposed to sublethal doses of crude oil. Bioscience Research Communication 15: 91-99.

20. Petrauskiene L (2003) Water and sediment toxicity assessment by use of behavioural responses of medicinal leeches. Environ Int 28: 729-736.

21. Maila MP, Cloete TE (2005) The use of biological activities to monitor the removal of fuel contaminants-perspective for monitoring hydrocarbon contamination: a review. International Biodeterioration \& Biodegradation 55 $1-8$

22. Xu FL, Jorgensen SE, Tao S (1999) Ecological indicators for assessing freshwater ecosystem health. Ecological Modelling 116: 77-106.

23. Dorn PB, Salanitro JP (2000) Temporal ecological assessment of oi contaminated soils before and after bioremediation. Chemosphere 40: 419426.

24. World Health Organization (1989) Report on International Programme on chemical safety, Environmental Health Criteria 83.

25. Cook AG, Critchley BR, Critchley U, Perfect TJ, Yeadon R (1980) Effects of cultivation and DDT on earthworm activity in a forest soil in the sub-humid tropics. Journal of Applied Ecology 17: 21-29.

26. Hickman ZA, Reid BJ (2008) The co-application of earthworms (Dendrobaena veneta) and compost to increase hydrocarbon losses from diesel contaminated soils. Environ Int 34: 1016-1022.

27. Oboh BO, Adeyinka Y, Awonuga S, Akinola MO (2007) Impact of soil types and petroleum effluents on the earthworm, Eudrilus eugeniae. J Environ Bio 28: 209-212. 